\title{
Neoproterozoic tectonic evolution of the Taimyr Peninsula (Arctic Asia): An example of a Late Precambrian thrust-fold belt
}

\author{
Geological Institute of the Russian Academy of Sciences, Pyzhevsky per. 7, Moscow, 119017, Russia. E-mail: la_sadovskaya@mail.ru
}

(Received: July 2, 2014: Revised accepted: October 13, 2014)

Structural relationships between the Neoproterozoic rock complexes of a continental massif, island arc and back-arc basin geodynamic affinities are described and considered in this work based on field observations within the northeastern segment of the Central Taimyr tectonic zone distinguished in the late Hercynian fold-thrust belt of the Taimyr Peninsula. As is established for the first time, rock complexes of the continental massif with the early Late Riphean (Tonian-Cryogenian) volcanogenicsedimentary cover occur in the study region as the allochthonous syn- and post-sedimentary thrust sheets buried in, or thrust over, deposits of a back-arc basin, which accumulated in the terminal Late Riphean (Cryogenian)-initial Vendian (Ediacaran). These and other results of the large-scale structural observations elucidate important details of the tectonic development in the Late Precambrian, when two lateral ensembles of the Neoproterozoic structures originated in the region. In the first half of the Neoproterozoic, the regional tectonic ensemble included the oceanic plate abutting on the continental massif with a volcano-plutonic belt. The subsequent system of an island arc and marginal back-arc basin originated in the second half of the Neoproterozoic and existed approximately till the midVendian (Ediacaran) phase of the intense formation of thrust sheets and folds (Baikalian orogeny).

\section{Introduction}

The Taimyr Peninsula is a key region for studying and deciphering the Precambrian history of thrust and fold belts flanking the Siberian platform. So, it has an important position among the main structures of the Arctic. That is why this region, which can be traced for almost $1000 \mathrm{~km}$, has attracted particular interest in many publications aimed at solving the tectonic problems concerning those belts. A series of published works have considered various models of the Taimyr tectonic evolution. Geological information related to Proterozoic rock complexes has been obtained in recent years. But this information includes above all some petrological-geochemical and geochronological data. The problems of Precambrian tectonics and geodynamic evolution were observed for the last time more than 10 years ago (Vernikovsky, 1996; Vernikovsky and Vernikovskaya, 2001). These works argued for the formation of the Neoproterozoic accretionary belt with ophiolite obduction and development of the Vendian (Ediacaran) tectonic thrust sheets. However this model only postulates tectonic imbrication but does not give any evidence for overthrust structures.

The main objective of this publication is to describe reliable examples of thrust sheets I have observed in the northeast of Taimyr (Fig. 1), to substantiate their origin at the end of the Precambrian with due consideration of geochronological dates known at present. Author suggests a plausible model of the regional tectonic development in the Late Precambrian, as the respective geological problems remain unanswered in many aspects so far. The results of observations considered below have been obtained by means of the large-scale geological survey during two seasons of fieldwork (surveyed areas are shown in Fig 2). Time spans accepted in the work for the Neoproterozoic subdivisions correspond to 1000-630 Ma for the Late Riphean and to 630-540 Ma for the Vendian.

\section{Tectonic Zones of Taimyr}

The Taimyr fold belt is divided into southern, central and northern tectonic zones separated from each other by the thrust faults of southward vergence. The belt has undergone two stages of deformation, i.e., Late Neoproterozoic and Late Paleozoic-Early Mesozoic (Zonenshain et al., 1990; Uflyand et al., 1991; Vernikovsky, 1996; Bogdanov et al., 1998; Inger et al., 1999).

\section{The South Taimyr zone}

This tectonic zone, bounded on the north by the Pyasina-Faddey thrust fault (Fig. 1), is composed of unmetamorphosed OrdovicianMiddle Carboniferous carbonate shelf deposits, which accumulated on the passive continental margin of Siberia. On the south, the carbonate sediments are overlain by an Upper Carboniferous-Lower Permian siliciclastic sequence grading upward into coal bearing sediments of the Upper Permian. All deposits are deformed by Sverging folds and thrusts, which decrease in intensity towards the south (Inger et al., 1999). 


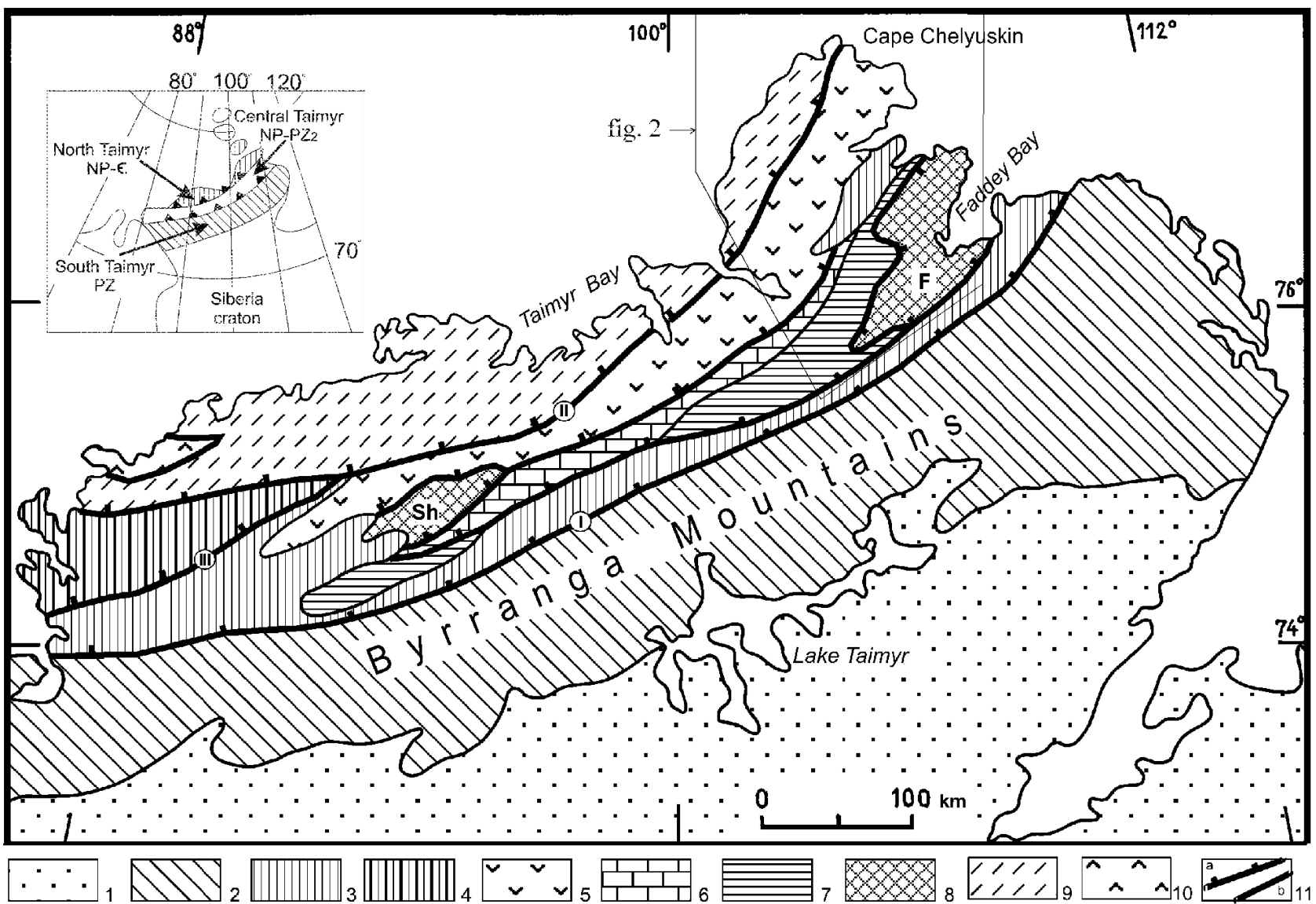

Figure 1. Simplified map of tectonic zones in Taimyr Peninsula comprising the Neoproterozoic and Paleozoic rock complexes of different geodynamic affinity. 1-deposits J-Q; 2-South Taimyr zone: carbonate shelf complex $\left(\mathrm{O}-\mathrm{C}_{2}\right)$ and siliciclastic sediments $\left(\mathrm{C}_{3}-\mathrm{P}\right)$ of the Siberian passive margin; 3-8-Central Taimyr zone: 3-4-slope facies of the Siberian Paleocontinent: 3-siliciclastic-carbonate $\left(V_{2}-\epsilon_{2}\right)$ and carbonatecherty-argillaceous $\left(\epsilon_{3}-C_{1}\right)$, 4-flyschoid $\left(V-\epsilon_{1}\right)$ and carbonate-siliciclastic-argillaceous $\left(\epsilon_{1}-O_{1^{-}}\right)$, 5-8-pre-Late Vendian complexes of: 5-island arc, 6-carbonate reefal belt, 7-marginal basin, 8-Shrenk (Sh) and Faddey (F) continental blocks; 9-10-North Taimyr zone: 9-siliciclastic flyschoid slope sediments $\left(R_{3}-\epsilon_{3}\right)$ of Kara plate, 10-volcanogenic island-arc complex $\left(R_{3}-V_{1}\right)$; 11-tectonic contacts: a-thrust faults (I-Pyasina-Faddey, II-Main Taimyr, III-Diabazovyi), b-faults of unclear types.

\section{The Central Taimyr zone}

In the Central Taimyr zone between the Pyasina-Faddey and Main Taimyr thrust faults, there are widespread the Neoproterozoic units of different geodynamic affinity. According to Uflyand et al. (1991), Vernikovsky (1996), and Pease et al. (2001), the units bounded by tectonic contacts almost everywhere correspond to blocks of continental crust, fragmented island-arc and back-arc basin complexes, and to a belt of carbonates with stromatolite bioherms. The internal structural features of the units are largely produced by thrust and reverse faulting of variable vergence. Geochemical information on the magmatic rocks of different geodynamic affinity have been provided by Vernikovsky (1996) and Proskurnin et al. (2014).

The continental blocks were formerly termed in publications as the Shrenk and Faddey terranes. These blocks are dominated by gneisses, crystalline schists, intrusive granites, granite-gneisses, and migmatites associated with less abundant orthoamphibolites, quartzites, and marbles. According to the results of the $\mathrm{U}-\mathrm{Pb}$ zircon dating, granite bodies intruded $846-833 \mathrm{Ma}$ ago the Faddey terrane and 894 - 885 Ma ago the Shrenk terrane (Proskurnin et al., 2014). It has been assumed that reservoirs of granite magma originated owing to reworking of the Meso- and Paleoproterozoic rocks metamorphosed in the Early Neoproterozoic time under conditions of amphibolite and epidote-amphibolite facies.

Rocks of the island-arc complex experienced greenschist metamorphism accompanied by the formation of high-angle foliation and closely-jointed cleavage. According to geochemical criteria, the original volcanics belonged to a differentiated calc-alkali series and were associated in places with tholeiitic basalts and shoshonites (Vernikovsky, 1996). The U-Pb zircon dates of $740 \pm 38$ and $755.1 \pm$ 7 Ma have been determined for plagiogranites that intruded basic to acid volcanics on the extreme northeast of Taimyr (Vernikovsky et al., 2004). The concordant $\mathrm{U}-\mathrm{Pb}$ age of $662 \pm 9 \mathrm{Ma}$ has been established for volcaniclastic rocks, whereas the latest manifestations of silicic volcanism have been dated at $627 \pm 7,625 \pm 4$ and $599 \pm 4$ Ma (Pease and Persson, 2006).

Dolomites, limestones, marls, and calcareous shales, which host stromatolites and microphytoliths of the Late Riphean are exposed, not far apart from and to the south of outcrops of the island-arc rocks. The shallow-water carbonates represent deposits of stromatolite bioherms, the chain of which separated the island arc from a back-arc basin. In the upper part of the carbonates there are thin flows of subalkaline trachybasalt lavas and interlayers of scoriaceous tuffs and also the basic necks and dykes crosscutting sediments. 
Deposits of the back-arc basin (see Fig. 1) are represented by silty to argillaceous shales and cherty sediments with horizons of volcanomictic turbidites and calcarenites. Isolated outcrops of volcanogenic rocks with island-arc geochemical characteristics are present too. Metamorphic grade of rocks corresponds to the greenschist (largely) and pumpellyite-prehnite facies. The rocks are deformed into multi-order folds of variable geometry, overturned sometimes toward the southeast and northwest. To the south of the Shrenk terrane, sediments in the upper third of the complex section bear acritarchs Chuaria nerjenica A. Weiss, Nucellosphaeridium nordium (Tim.), and Cephaloonyx sp. characteristic of the Late Riphean-Vendian (conclusion of A.F. Weiss).

All of the considered rock complexes were folded and thrust together in the latest Neoproterozoic and formed an accretionary belt conjoined with Siberian paleocontinent. Rocks of the belt are discordantly overlain by unmetamorphosed sediments of the Late Vendian-Middle Paleozoic (Uflyand et al., 1991; Vernikovsky, 1996; Vernikovsky et al., 2004). The basal rudaceous member of the respective sedimentary cover is overlain by shallow-water siliciclastic and carbonate deposits $\left(\mathrm{V}_{2}-\epsilon_{2}\right)$ grading upward into deeper water sediments, represented by carbonaceous shales with phthanites $\left(€_{3}-\right.$ $D_{2}$, including $C_{1}$ on the west). The sediments are variably deformed: large brachysynclines are observable on the northeast, whereas isoclinal folds are widespread within the extended thrust-fault zones. The Late Paleozoic-Early Mesozoic(?) folding was upright to Svergent. The western wedge-shaped block between the Diabasovyi and Main Taimyr thrust faults is composed of intensively dislocated flyschoids $\left(\mathrm{V}-€_{1}\right)$ and carbonaceous shales $\left(€_{1}-\mathrm{O}_{1-2}\right)$. The deposits listed accumulated on the continental slope of Siberia after accretion to it the rock complexes of the Central Taimyr zone during the Late Baikalian tectonic epoch (Inger et al., 1999).

\section{The North Taimyr zone}

This zone is dominated by rhythmically interbedded psammitic to silty and pelitic detrital sediments. The metamorphic grade of these flyschoids, which are deformed into isoclinal faulted folds, changes from the greenschist- to amphibolite-facies. Many researchers regard these sediments as the slope deposits of the Kara continental plate (Zonenshain et al., 1990; Uflyand et al., 1991; Vernikovsky, 1996). The sedimentation dated by clastic zircons and acritarchs proceeded during the interval $\mathrm{R}_{3}-\bullet_{3}$.

On the west of the North Taimyr zone there are known outcrops of altered volcanogenic and intrusive rocks of the island-arc type. Isotopic dates characterizing these rocks are $703 \pm 11$ and $692 \pm 10$ Ma (Pease and Persson, 2006). Outcrops of these rocks are localized in a tectonic window beneath the North Taimyr sediments, which were thrusted in the terminal Paleozoic (Vernikovsky, 1996). Probably, the igneous rocks belonged to an island arc situated apart from the arc of the Central Taimyr zone.

The structure of sedimentary deposits is complicated by widespread Late Paleozoic granitoids (306-275 Ma). These rocks were formed during collision of the Siberian and Kara plates (Zonenshain et al., 1990; Uflyand et al., 1991; Vernikovsky, 1996). In the eastern part of the peninsula, the post-collisional granitoids (265-250 Ma) intruded as well the rock complexes of the Central Taimyr zone (Vernikovsky, 1996).

Structural relationships between different rock complexes, which originated during the Baikalian orogeny, are preserved comparatively well on the northeast of the Central Taimyr zone, where they have been the least affected by the Paleozoic and later tectonic movements. As is shown below, the thrust sheets observable here undoubtedly originated in the pre-Late Vendian time.

\section{Neoproterozoic Complexes on the Northeast of Central Taimyr Zone}

\section{Continental massif}

The oldest high-grade metamorphic rocks, which have been studied on the northeast of the Central Taimyr zone in isolated but closely spaced outcrops with intricate contours in the plane view (Fig. 2), are regarded as the Faddey crystalline complex. Fragmentarily preserved sedimentary cover discordantly overlying crystalline rocks of the formerly integral massif were deposited in subaerial and shallow-water environments. The basal sediments of the cover accumulated in separate grabens most likely are of very variable thickness (Fig. 3). These are quartz to arkosic sandstone, gravelstones, and polymictic conglomerates crowned by a dolomite member. The

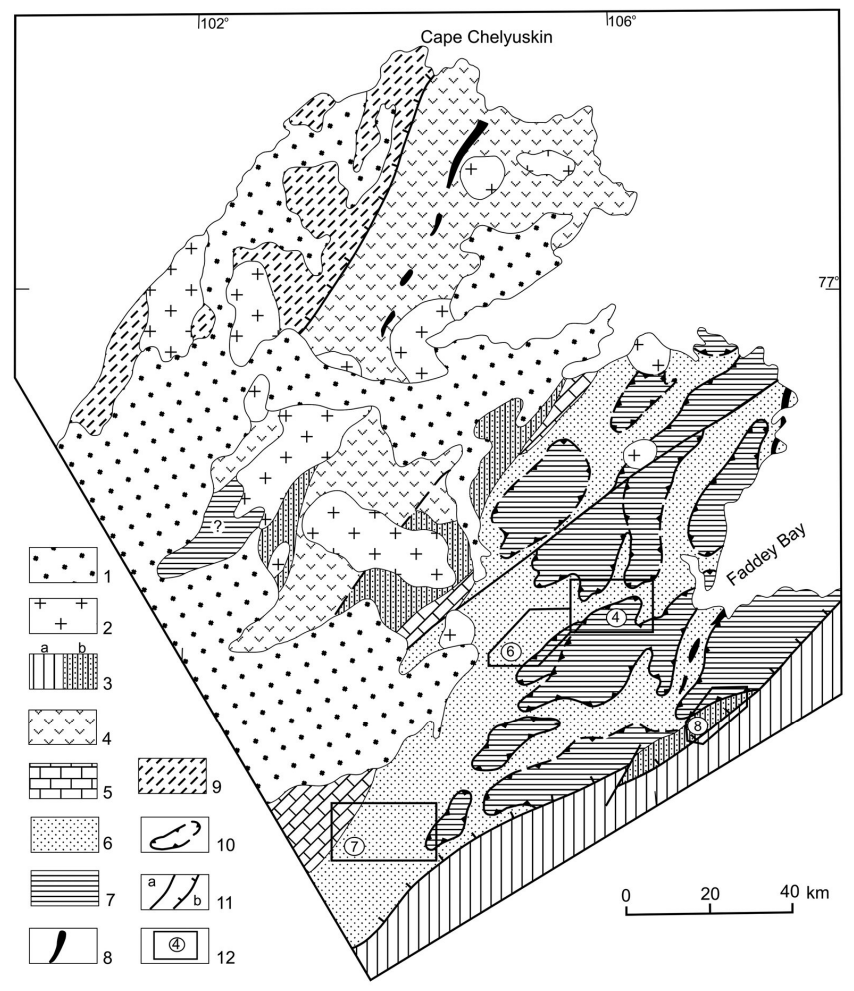

Figure 2. Distribution of different rock complexes on the northeast of Taimyr (see the area position in Fig. 1). 1-Jurassic-Cenozoic cover; 2-Late Paleozoic granitoids; 3-Ordovician-Devonian (a) and Late Vendian-Middle Devonian (b) sedimentary complexes; 4-8pre-Late Vendian complexes of Central Taimyr zone: 4-island-arc volcanics $\left(R_{3}^{2}-V_{1}\right), 5$-carbonates of reefal belt $\left(R_{3}^{2}\right)$, 6-deposits of back-arc basin $\left(R_{3}{ }^{2}-V_{1}\right)$, 7-rocks of the Faddey massif (MP, $\left.R_{3}{ }^{1}\right)$, 8-ophiolites at the base of island-arc and back-arc basin complexes; 9-flyschoid complex $\left(R_{3}-\epsilon_{3}\right)$ of North Taimyr zone; 10-boundaries of Vendian thrust sheets; 11-Late Paleozoic faults (a) and thrust faults (b); 12-contours of study areas illustrated in the figures 4, 6 , $7,8$. 


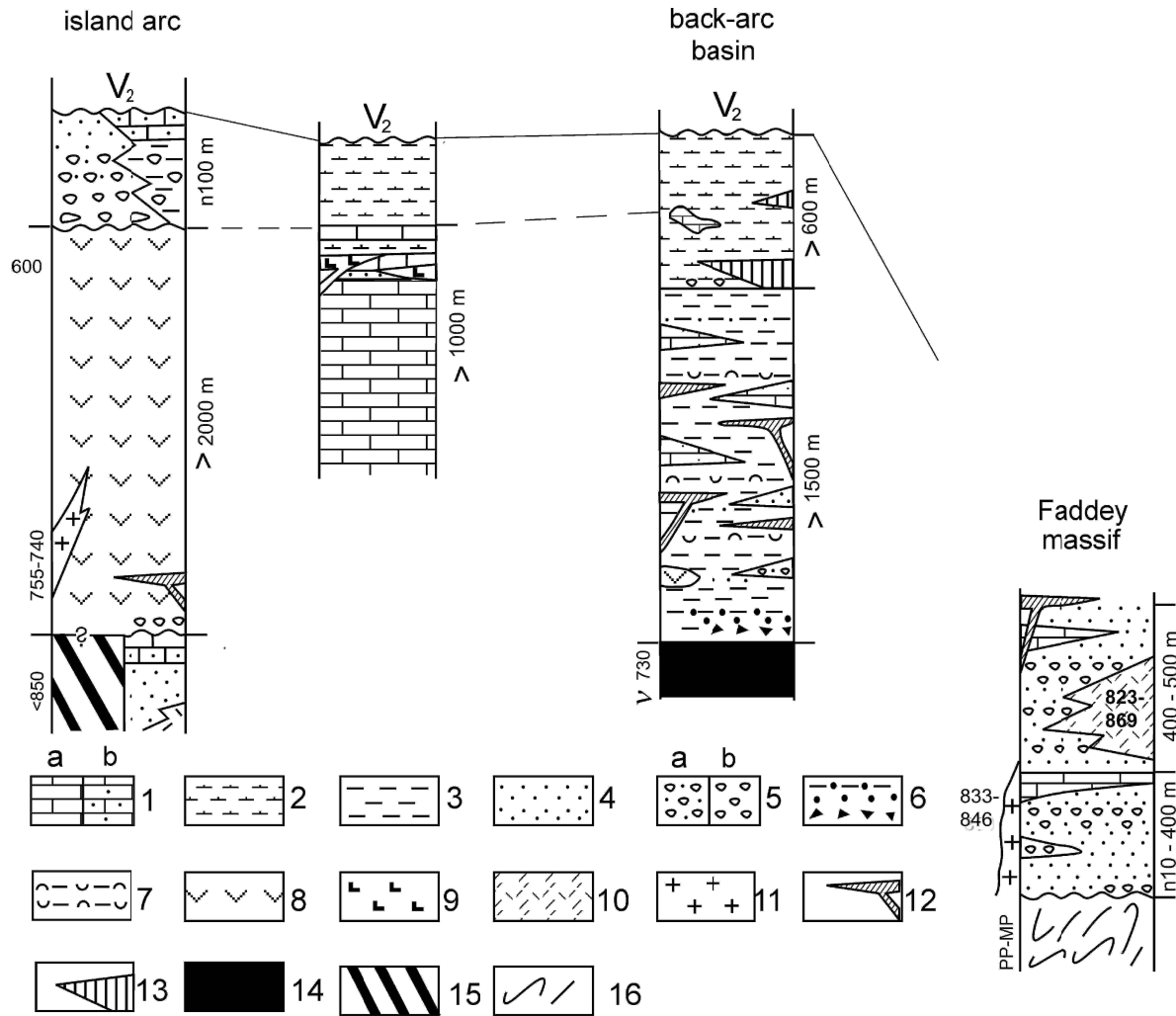

Figure 3. Generalized lithostratigraphic columns of pre-Late Vendian complexes studied on the northeast of Central Taimyr zone. 1-carbonate rocks (a), including varieties with siliciclastic admixture (b); 2-variegated calcareous, argillaceous and silty shales; 3-black carbonaceous shales with phthanite interlayers; 4-sandstones; 5-gravelstones (a), conglomerates or pebbles and boulders in mixtites (b); 6-edaphogenic breccia-conglomerates, sandstones, and siltstones; 7-tuffaceous cherty sediments; 8-differentiated island-arc volcanics, 9-subalkaline basic volcanic rocks, 10-silicic lavas of volcano-plutonic belt; 11granites; 12-diabase and gabbro-diabase sills and dykes; 13-slumped allochthonous rock units; 14-ophiolites; 15-accretionary wedge; 16-crystalline complex. Figures to the left of columns designate geochronological age, Ma; v-gabbro; PP-MP-PaleoproterozoicMezoproterozoic; $V_{2}$-Late Vendian.

rudaceous fraction of sediments represents poorly sorted and variably rounded erosion products of the basement rocks and the matrix of conglomerates is colored red in many cases. Higher in the section, sediments composed predominantly of quartz and plagioclase clasts cemented by carbonate material contain pebbles of basement rocks and underlying sediments. Sedimentary strata intercalated with silicic fluidal lava flows and tuff interbeds host both subvolcanic felsite, plagiophyre and orthophyre bodies and volcanomictic intercalations (Samygin, 2012). According to the results of the U-Pb zircon dating, rhyolites are as old as $869 \pm 3,846 \pm 7$ and $823 \pm 5 \mathrm{Ma}$ (Proskurnin et al., 2014). The metamorphic grade of rocks transformed into quartzite, marbles, and porphyroids corresponds to the greenschist facies.

Widespread leucocratic pseudoporphyritic granites dated at 846 \pm 11 and $833 \pm 5 \mathrm{Ma}$ and referred to the I-type of a calc-alkaline series (Proskurnin et al., 2014) represent, with silicic metavolcanics, a comagmatic association that originated in the first half of the Late Riphean. Hence, sedimentary cover of the Faddey massif accumulated at the time of concurrent magmatic activity that resulted in emergence of the Late Riphean volcano-plutonic suite of suprasubduction origin (Samygin, 2012). The latest metadiabase dykes and sills intruded the basement rocks and sedimentary cover of the massif.

\section{Island arc}

A series of works (Uflyand et al., 1991; Vernikovsky, 1996; Pease and Persson, 2006), substantiated the past existence in Taimyr of an island arc, the volcanic activity of which lasted approximately from 750 to $600 \mathrm{Ma}$ according to isotopic dates, i.e., during the terminal Riphean-initial Vendian. In proximity to the Main Taimyr fault, there are exposed remnants of comparatively large poly- and monogenetic volcanoes of the axial zone. The earlier products of eruptions are represented by rocks of basaltic to andesitic composition; the main rock types of the later eruptions are dacites, rhyolites including ignimbrites. Diverse rudaceous facies crowning the volcanogenic succession originated by deep erosion of the island-arc structure (see Fig. 3). Southeastward of the axial zone, conglomerates and breccias with abundant silty-pelitic matrix characterize the channel facies of submarine fans, through which the coarse clastics were transported on the island-arc slope.

The basement of the island-arc, locally exposed in the northern part of study area, consists of an older accretionary complex. The latter might have formed as a tectonic wedge in front of the suprasubduction volcanoplutonic belt, which evolved on the edge of the Faddey massif (older continental arc) 870$820 \mathrm{Ma}$ ago. The exposed part of the accretionary complex, up to $4 \mathrm{~km}$ across, is composed of vertical and high-angle tectonic slivers and lenses up to $500 \mathrm{~m}$ in thickness. Remarkable components are serpentinized ultramafics, massive and banded gabbro, metamorphosed tholeiitic basalts, and lenses of serpentinite mélange. Sedimentary rocks involved in the accretionary structure are comparable in composition with deposits overlying the Faddey massif but are finer grained.

The accretionary wedge that formed at the front edge of the Faddey continental massif incorporated tectonic slices and slivers of its sedimentary cover and redeposited erosion products derived from the volcano-plutonic belt which accumulated in the upper parts of the massif slope and deeper levels. Slivers of ophiolitic rocks represented fragments of disintegrated oceanic crust situated in front of the wedge. The Sm-Nd model age of that crust corresponds to 785-850 Ma (Vernikovsky et al., 2004).

\section{Back-arc basin}

Sediments of the back-arc basin can be divided in two lithostratigraphic units (Samygin, 2012): the lower black-shale and overlying variegated shale sequences (see Fig. 3). The lower sequence is composed of carbonaceous shales with thin phthanite interlayers, fine-grained pyroclastic material from local volcanic centers inside the basin, separate beds of carbonate turbidites, and dispersal arkosic 
material derived from the Faddey massif. A distinctive feature of the black-shale sequence is numerous sills and rare dykes of diabases and gabbro-diabases are confined to it within a belt over $10 \mathrm{~km}$ wide. Being from a few to tens meters thick and up to several kilometers long, sills and conformable sedimentary strata are jointly folded.

A chain of lengthwise extended serpentinite lenses up to $300 \mathrm{~m}$ thick in total is exposed among carbonaceous shales, metatuffs, and marmorized limestones to the southeast from the belt of sills (see Fig. 2). In the northern flank of the ophiolite outcrops (the Faddey Bay coasts), a strongly reduced section of oceanic crust that floored the black-shale sequence is preserved. The vertical lens of serpentinites after harzburgite with relict banded structure is separated by a blastomylonite zone from gabbro and pyroxenites thickly pierced by diabase veins forming a kind of stockwork. To the southeast of this site there are exposed diabases and metabasalts, and farther away the black shales with a member consisting of edaphogenic sandstones and siltstones. These rocks overlie breccia formed due to disintegration in situ of gabbroids and mylonitized basalts. The U-Th- $\mathrm{Pb}$ age of gabbro sampled from this section corresponds to $729.8 \pm 7.1 \mathrm{Ma}$. In southern outcrops of ophiolitic rocks, lenticular bodies of altered gabbro are surrounded by tholeiitic basalts transformed into garnet amphibolites with isotopic dates of metamorphic events as $624 \pm 16$ (Ar-Ar), $606 \pm 44(\mathrm{Rb}-\mathrm{Sr})$ and $573 \pm 78$ (Sm-Nd) Ma (Vernikovsky et al., 2004).

The more uniform sedimentary facies of the upper variegatedshale sequence accumulated in shallower sedimentation settings without the influence of magmatic activity. Prevailing among them are greenish, lilac and darker colored ribbon slates, siltstones, and fine-grained sandstones frequently calcareous, foliated or transformed into phyllites. Rudaceous sedimentary horizons and members with slump structures occur closer to the base of the sequence. As shown below, these allogenic deposits also occur in lesser amounts higher in the section and are comparable in lithology with the sedimentary cover of the Faddey massif. To the west, upper strata of the variegatedshale sequence overlaps dolomites and rises to enclose its olistoliths.

The rock complex of the back-arc basin is concurrent in general to the island-arc complex (see Fig. 3). The commencement time of their formation is unknown precisely, but soon after emergence of the early island-arc magmatic rocks $755-740 \mathrm{Ma}$ ago, the basin was floored by crust of the oceanic type that is evident from the date of $730 \mathrm{Ma}$ estimated for ophiolitic gabbro. The stockwork of diabase veins discovered in outcrops of ophiolitic rocks appears to be indicative of the tectonic extension in the basin. Such settings were discussed in detail using examples from the Lower Paleozic ophiolites in Mongolia (Samygin, 2012 and references therein). The extended belt of diabase sills situated closer to the island arc than the chain of ophiolite outcrops can be interpreted as evidence of subsequent extension and widening of the basin. These considerations are evidence of the back-arc position of basin.

The island arc northwest of the back-arc basin was connected with the subduction zone dipping to the southeast (in coordinates of Fig. 2). Arc polarity is evidenced by the position of the Late Riphean carbonate reef complex and associated subalkaline volcanics extending over a distance of $400 \mathrm{~km}$. The southeastern part of this complex is overlain by the upper horizons of deposits accumulated in the backarc basin. The Faddey continental massif that bounded the basin on the opposite side served as the source of siliciclastic material transported into the basin.

As is evident from the data considered above, two lateral series of the Neoproterozoic structures are distinguishable on the northeast of the Central Taimyr zone. The structural ensemble of paleooceanic basin, continental massif with suprasubduction volcano-plutonic belt, and accretionary wedge at the boundary with the basin existed in the first half of the Neoproterozoic (since $870 \mathrm{Ma}$ at least). Remnants of oceanic crust that are presumably 850-785 Ma old occur as ophiolite slivers in the accretionary wedge. The original lateral relationships between these mentioned structures were destroyed by tectonic processes of the second half of the Neoproterozoic, which gave rise to development approximately $750 \mathrm{Ma}$ ago of the island arc with the rear reefal belt and back-arc basin with oceanic crust as old as 730 $\mathrm{Ma}$ at least. The basin was bordered on the other side by greater part of the continental massif left after its destruction by crustal extension. The basement of the island arc perhaps included the accretionary wedge and marginal part of the Faddey massif. During the Baikalian and Hercynian orogenic movements, rock complexes corresponding to this structural ensemble were variably deformed, fragmented, and tectonically imbricated, but the general relationships between them remained unchanged. Fragments of the Faddey continental massif occurring at present as allochthonous structural elements amid complexes of the back-arc basin represent an exception (see Fig. 2).

\section{Thrust Sheets of the Northeastern Taimyr}

Isolated fragments of the Faddey crystalline complex are widespread in the region (see Fig. 2). Their outcrops, confined to the elevated relief forms, are surrounded everywhere without stratigraphic relationships by the basin deposits accumulated in the relatively deep sedimentation settings. External boundaries of the respective bodies cut the elements of their internal structure at diverse angles. Along the boundaries, the rocks experienced strong cataclasis, mylonitization, and low-T diaphthoresis. Near the boundaries, the black shales are chaotically deformed and dismembered into separate slivers and sheets (broken formation). In many places, they host small embedded blocks of crystalline rocks (Fig. 4).

Fragments of the Faddey massif are the allochthonous rock units. Thrust sheets and klippen of crystalline rocks accompanied by a trail of smaller blocks are surrounded by phyllites and sandy-silty sediments belonging to the upper variegated-shale sequence of the back-arc basin (Fig. 5). In the Faddey riverhead area, some sheets of crystalline rocks retained basal part of their shallow-water carbonate-siliciclastic cover. The higher horizons of the covering sediments have been detached from those remained in situ and proved to be buried after gravity sliding between the black-shale and variegated-shale sequences in a form of extended olistoplaque that marks a syncline doubled by thrusting. The olistoplaque with a sharp sole boundary is up to 250$280 \mathrm{~m}$ thick. Its section begins with pebbly to bouldery conglomerates, in which well-rounded pebbles of quartzite-like sandstones are associated with clasts of carbonate rocks, granitoids, and schists. The matrix of these conglomerates corresponds in composition to quartz and quartz-plagioclase sandstones. The sediments enclose thin flows of hematitized silicic lava. Conglomerates grade upward into quartz sandstones with carbonate cement overlain by dolomites with an admixture of quartz grains. The olistoplaque section is crowned by limestone and is conformably overlain by phyllites belonging to the variegated-shale sequence. In the northwestern limb of syncline (see Fig. 5), green to lilac thin phyllite interlayers are intercalated with sediments composed of quartz grains. The extremely shallow-water sediments of the olistoplaque are certainly allogenic with respect to 


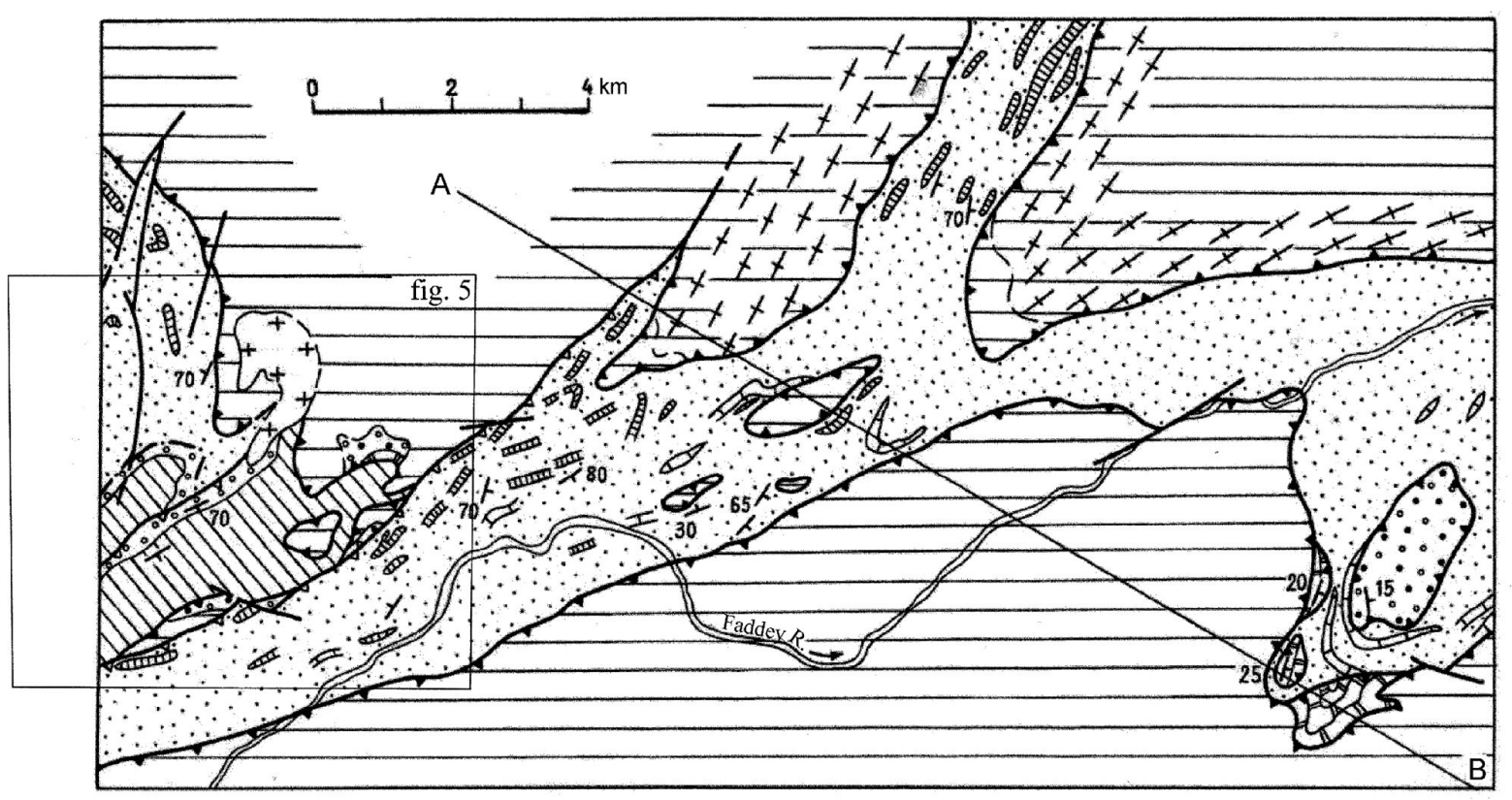

A

B
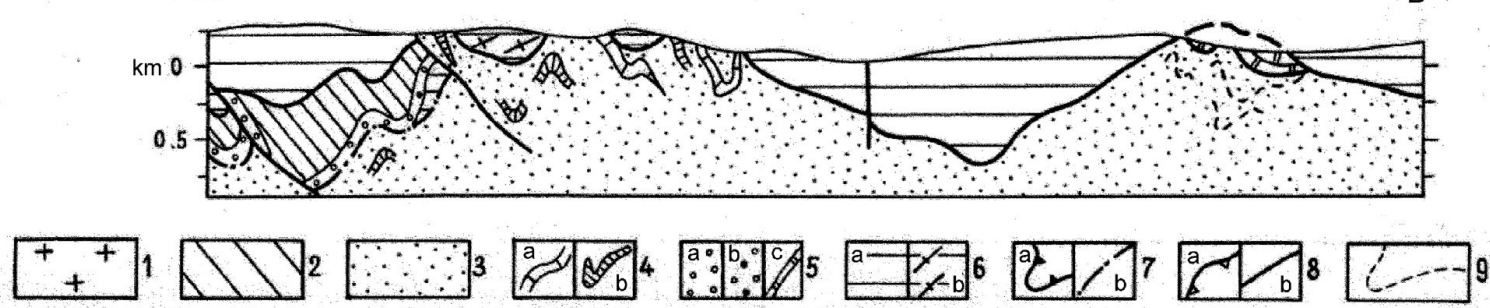

Figure 4. Geological scheme of upper to middle reaches of the Faddey River (see the area position in Fig. 2). 1-Late Paleozoic granitoids; 2-4-back-arc basin complex: 2-variegated-shale sequence, 3-black-shale sequence, 4-carbonate sediments (a), metadiabase sills (b); 5-6Faddey massif: 5-covering rudaceous sediments in situ and in allochthonous occurrence (a), sandstones and subordinate gravelstones (b), carbonates (c), 6-crystalline complex (a), in particular granite-gneisses (b); 7-sole of tectonic nappe (a) and of synsedimentary slump sheet (b); 8-thrust and reverse faults (a), other faults (b); 9-strike of bedding and metamorphic banding.

underlying and overlying deposits accumulated in much deeper sedimentation settings.

From the Faddey riverhead, the syncline extends far to the southwest (Fig. 6), where its southeastern limb is partially overridden by tectonic nappe composed of quartzite-like sandstones, gravelstones, and porphyroids after silicic tuffs. Near the nappe sole there is exposed in places an olistostrome horizon deposited due to the disintegration of the frontal part of the nappe. In this horizon, the variably sized and shaped clasts of gray coarse-grained arenite are cemented by a dark silty-argillaceous matrix with laminae of fine- to medium-grained sandstones (see sketch in Fig. 6). Below the horizon there are exposed rocks of the variegated-shale sequence with slump-fold hinges facing westward.

Among phyllites exposed along the northwestern limb of syncline, a series of horizons of approximately one stratigraphic level can be traced. These are composed of submarine slump deposits close in lithology to sediments of the nappe thrust over the southeastern limb. Below these horizons there is, fragmentarily exposed, the basal member of the variegated-shale sequence with pebbles and boulders of quartzite-like sandstones and subordinate granites. The member thickness and degree of its saturation with pebbles and boulders decrease in the southwestern direction. The basal member characterizes the lateral transportation of rudaceous sedimentary

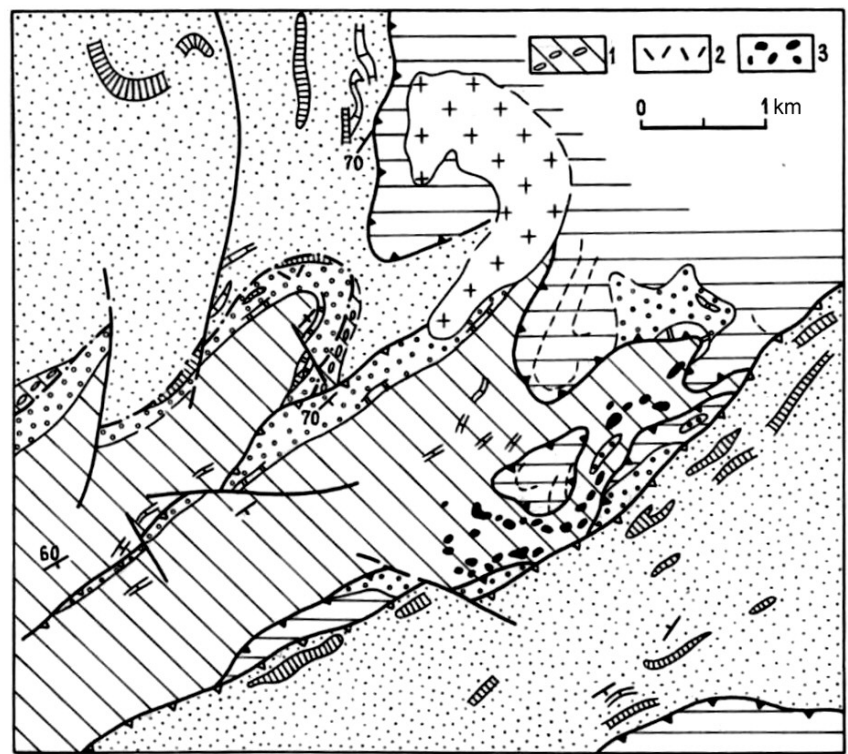

Figure 5. Geological structure of the Faddey riverhead area (see the area position in Fig. 4).1-mixtites at the base of variegatedshale sequence; 2-acid volcanics; 3-blocks of crystalline rocks. Other symbols as in Fig. 4. 


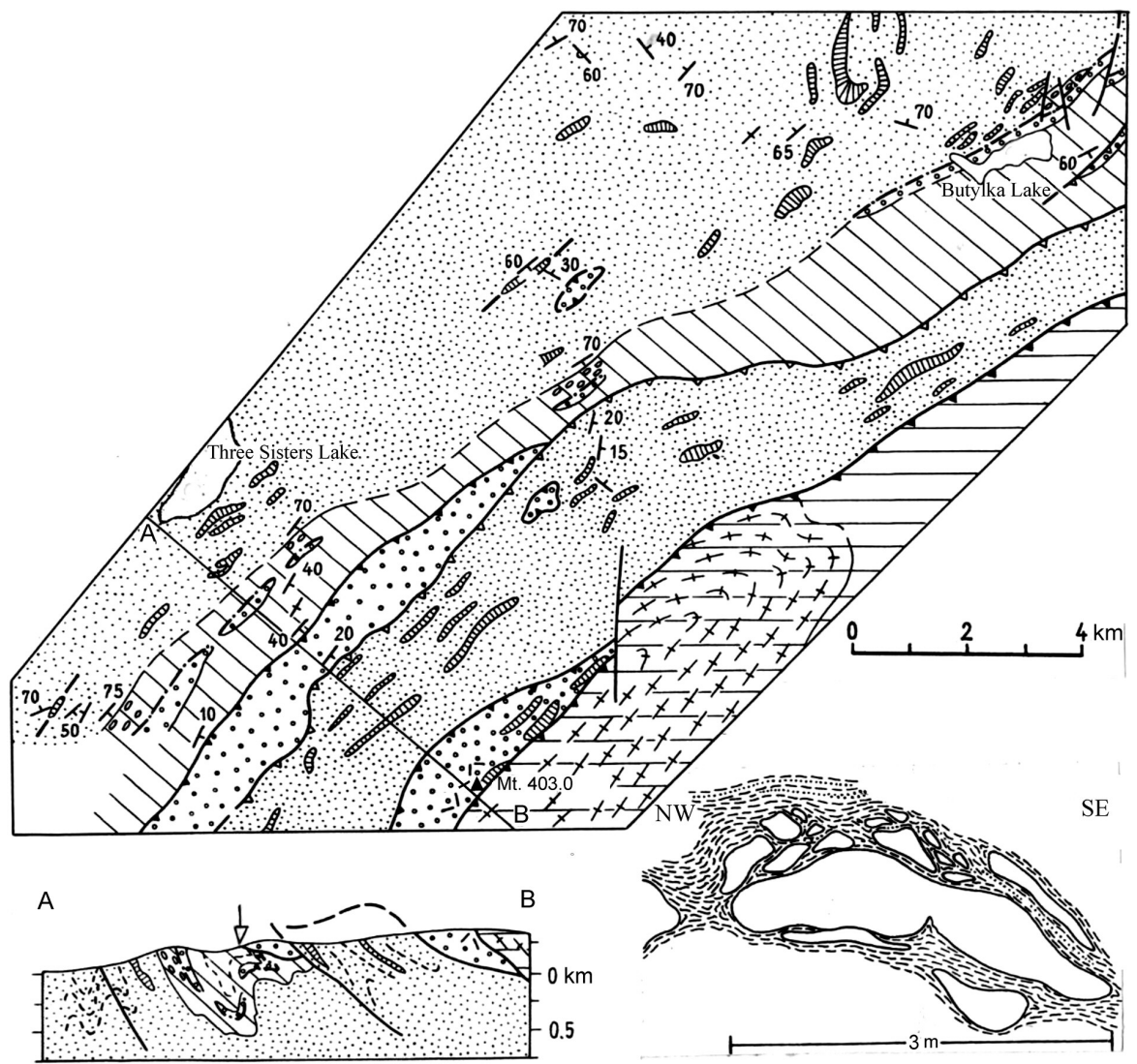

Figure 6. Geological scheme of area between the Three Sisters and Butylka lakes (see the area position in Fig. 2). Symbols for lithology as in Figs. 4 and 5; sketch described in the text is drawn at the point shown by arrow in profile.

material derived from destruction of a large thrust sheet that detached from the sedimentary cover of the Faddey massif and slumped into the basin. A remnant of the thrust sheet is exposed at the base of the variegated shale sequence to the northeast, in the Butylka Lake area.

The same situation is observable on the right side of the Leningradskaya River (Fig. 7). The largest sliver of sedimentary cover that formerly rested on the crystalline basement is confined here to the base of variegated shales overlying the black-shale sequence of the back-arc basin. Among the lower quartzite-like sandstones there are conglomerates with variably rounded clasts of metaquartzites, silicic volcanics, diverse carbonate rocks, and subordinate amphibolites. Above these rocks, resting on subvolcanic plagiophyres, the grain size of clasts decreases upward. Fine-grained sandstones are overlain by variegated phyllites with thin siltstone interlayers. The less extended and thinner olistoplaques of quartzite-like rocks occurring among the phyllites presumably corresponded to horizons of sedimentary cover formerly located closer to its base.

The basal contact of olistoplaques is very sharp everywhere. Their spatial distribution suggests that they slumped into the marginal basin from the other extremely shallow-water facial zone situated on the east (in current coordinates). At the same time, there was the western source zone of the other allochthonous inclusions exotic to the phyllite sequence, i.e., of a large reefal buildup of the Late Riphean stromatolitic dolomites. Dolomitic olistoliths occur as oblong or isometric bodies of intricate shape (see Fig. 7) consisting of sizevariable blocks. They characterize the avalanche talus derived from the reefal buildups on a horst uplift that bounded the marginal basin on the west.
As already mentioned, original relationships between the carbonateterrigenous sedimentary cover and crystalline basement are retained in individual cases only (see Fig. 5 for instance). In the other cases, rocks of the crystalline basement override their own blanket deposits of shallow-water origin detached previously and slumped into the marginal basin. An example is observable on the right side of the middle reaches of the Faddey River (Fig. 4). Characteristic structural relationships can also be established in the Mt. Urvantsev area (Fig. 8), where a linear anticline has been mapped near the Hercynian thrust fault. The anticline core is of synform structure, consisting of a comparatively thin unit of coarse-grained arkosic and polymictic (clasts of quartzite, amphibolites, crystalline schists, and granophyres) deposits almost without cement and higher carbonate beds which here underlie diaphthorites after crystalline schists and granite-gneisses. Along the contact, the underlying rocks are strongly foliated; carbonates are deformed and marmorized. In this case there are no doubts that granitized and repeatedly altered rocks of the fold core rest on terrigenous and carbonate deposits of their former sedimentary cover. In the anticline limbs there are exposed the Upper Vendian stromatolitic dolomites and limestones grading upward and, partially, laterally into argillaceous shales with thin limestone interlayers and overlying the basal gravelstones and phosphatic breccias. This unmetamorphosed sequence can be regarded as a neoautochthon that sealed a thrust sheet deformed into the synform prior to the Late Vendian.

\section{Nappe Thrusting, Sedimentation and Metamorphism}

The considered data provide evidence of the allochthonous occurrence of the early Late Riphean continental rocks among the younger rocks of the nearby marginal basin. In terms of the presentday coordinate system, the allochthonous rock complexes have been transported from the east to west or northwest. The respective tectonic events commenced after deposition of the black-shale sequence and maximum deepening of the basin. Movements of thrust sheets or nappes were accompanied by their disintegration, slumping into the basin, and by embedding of crystalline blocks into consolidated sediments of the basin marginal zones. The embedding was responsible for the local appearance of chaotic structures in the basin sediments. Moreover, movements and tilting of continental blocks caused tectonic delamination of their sedimentary cover, detachment of thrust sheets and gravity slumping into the basin. Slumping tectonic sheets partly disintegrated supplying the basin with reworked debris. This material was transported by submarine currents over the basin floor.

The intense slumping of tectonic sheets and accumulation of abundant products of their destruction and erosion resulted in 


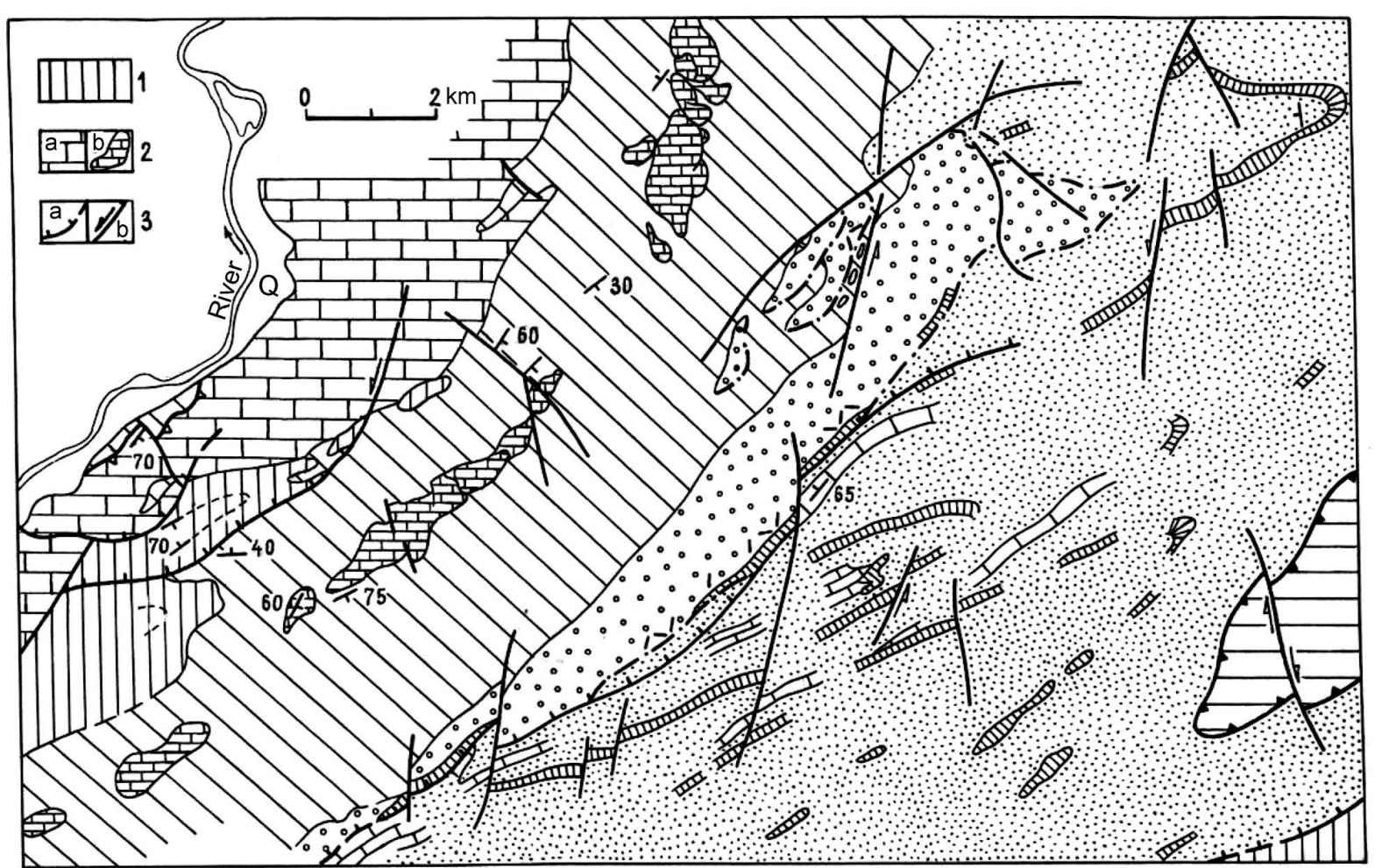

Figure 7. Geological scheme of area on the right side of the Leningradskaya River (see the area position in Fig. 2). 1-Lower Paleozoic deposits; 2-Upper Riphean dolomites (a), their olistoliths (b); 3-Late Paleozoic reverse faults and thrusts (a), strike-slip faults (b). QQuaternary. Other symbols as in Figs. 4 and 5.
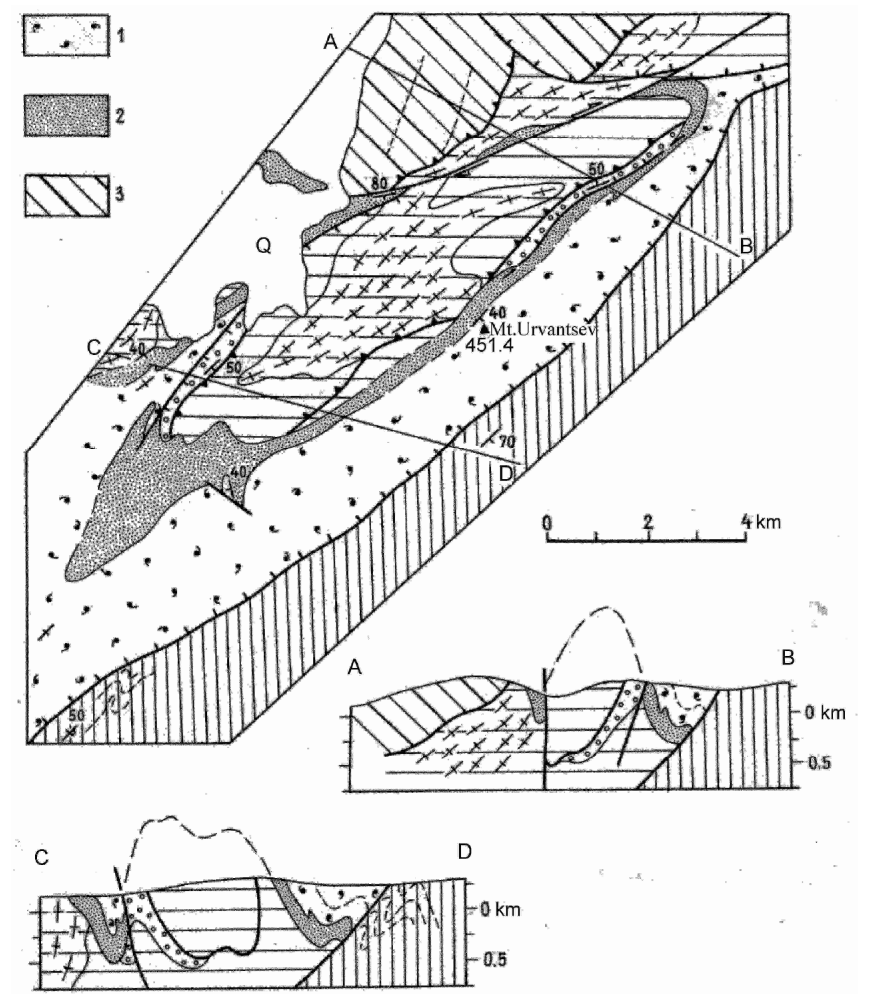

Figure 8. Geological scheme of the Mt. Urvantsev area (see the area position in Fig. 2).1-2-Upper Vendian deposits: 1-silty shales with carbonate interlayers, 2-dolomites and limestones; 3crystalline complex, predominantly amphibolites. Other symbols as in Figs. 4 and 7. perceptible shallowing of the marginal basin. In the axial part of basin, displaced closer to its western boundary, black shales were overlain by the variegated-shale sequence with numerous allochthonous rock units and abundant accumulations of debris materials produced by their destruction and redeposition. In places, the fragments of crystalline complex were thrust over allochthonous slices detached from sedimentary cover of crystalline rocks, and the most advanced nappes overrode the variegated-shale sequence in westerly areas of the basin (see Figs. 2, 4, 5). The ultimate closure of the basin that happened approximately in the mid-Vendian time was accompanied by metamorphism of oceanic crustal rocks beneath deposits close in age to $600 \mathrm{Ma}$ (Vernikovsky et al., 2004).

Vergence of the Baikalian dislocations in Taimyr produced by overthrusting was opposite to the southwestern vergence of fold and thrust structures formed at the end of the Paleozoic. The Hercynian tectogenesis of discrete character generally affected the Baikalian structures weakly. In areas occupied by the Vendian thrust sheets, the primary vergence of rank-variable folds and faults remained unchanged in many places (see profiles in Figs. 4 and 6).

\section{Tectonic Development of Taimyr in the Late Precambrian}

A simplified scenario of the Taimyr tectonic development during the Neoproterozoic can be summarised. Subaerial and shallow-water deposits of sedimentary cover overlying the Faddey crystalline massif accumulated in the early Late Riphean. Subduction of the adjacent oceanic plate commenced at about $870 \mathrm{Ma}$ and led to formation of the continental arc (volcano-plutonic belt) on the 
a)

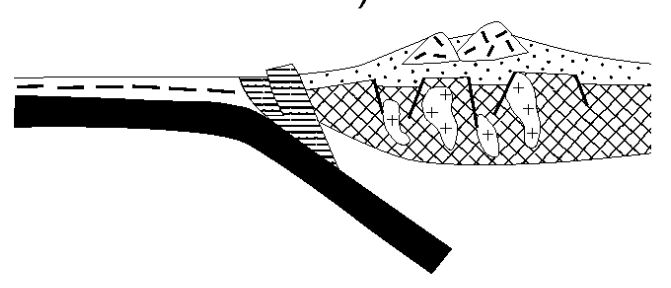

b)

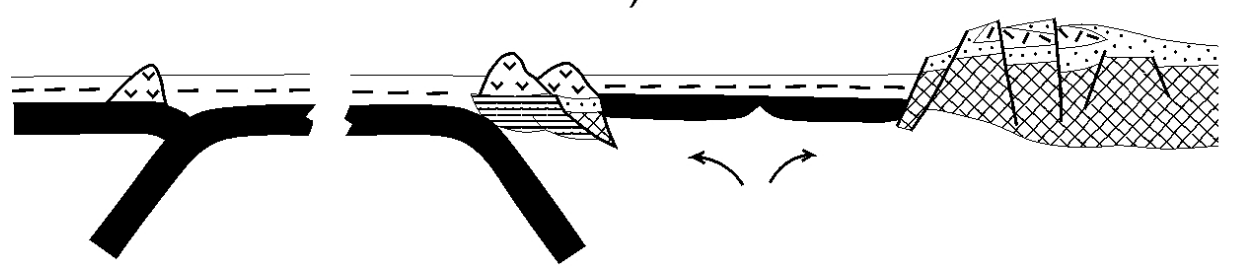

c)
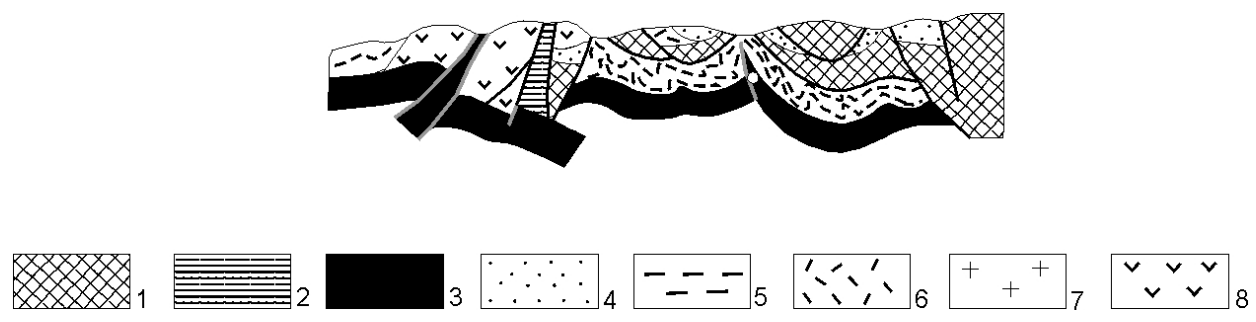

Figure 9. Schematic paleoprofiles across Central Taimyr zone for time intervals of 900-800 Ma (a), 730-600 Ma (b), and 600-585 Ma (c).1-continental crust; 2-accretionary wedge; 3-oceanic crust (white circle on cartoon c)-the location of garnet amphibolites); 4-subaerial and shallowwater sediments; 5-deep-water deposits; 6-7-marginal volcano-plutonic belt: 6-acid volcanics, 7-granites; 8-differentiated island-arc volcanics.

massif. In front of the belt, the accretionary wedge included tectonic slices of the adjacent oceanic plate (Fig. 9a). The subsequent pulse of subduction and relevant magmatic activity gave rise in the second half of the Late Riphean (750 Ma ago) to the development of island arc above the accretionary wedge and thinned marginal zone of the continental massif. Somewhat later, crustal extension behind the arc and destruction of the crystalline massif triggered opening of the back-arc basin floored by oceanic crust (730 Ma). Subsequent widening and deepening of the basin was perhaps associated with the back-arc spreading (Fig. 9b), an indication of which could be the basic sills and dykes of an extended belt inside the basin.

Deepening of the back-arc basin with oceanic crust might cause isostatic upwarping within adjacent continental massif leading to instability and deformation of the continental margin. Splitting of the massif into blocks and their tilting caused delamination of sedimentary cover and episodic detachment of its tectonic slices, which sometimes included basement rocks (see Fig. 5), and slumped into the adjacent basin. Cessation of the back-arc basin widening soon afterwards and accumulation in a great volume of slumped rocks and associated debris material partly infilled the basin: black shales were replaced by variegated shales.

The development of island-arc system ended in the mid-Vendian time about $600 \mathrm{Ma}$ ago interrelated with the cessation of subduction. Crustal extension behind the arc gave place to tectonic compression.
Deformation thickening and transverse contraction of the high-standing Faddey massif caused thrusting of its fragments over the marginal basin, where movements of thrust sheets were accompanied by folding and faulting in the sediments. Rocks at the base of the basin deposits were transformed into garnet amphibolites (Fig. 9c).

After the period of nappe formation, the Late Baikalian phase of folding affected totally the Central Taimyr zone. The Baikalides, accreted to the Siberian craton, became part of its renewed passive margin where sedimentary complexes of continental slope accumulated after the late Vendian. It is unclear what triggered the Late Baikalian tectogenesis and why the subduction under the island-arc system of the Central Taimyr zone ceased in the midVendian. The former existence of oceanic plate that could be involved into the postulated subduction zone is shown in paleogeodynamic reconstructions (Vernikovsky and Vernikovskaya, 2001; Kheraskova et al., 2010). We can assume that the plate included an intraoceanic island arc (see Fig. 9b) now observed on the west of the North Taimyr zone. Collision between this arc and the Central Taimyr island arc could stop subduction and simultaneously lead to development of progressive tectonic compression in the crust responsible for the Baikalides appearance in Taimyr.

\section{Conclusions}

The occurrence of Precambrian tectonic nappes in the Late Hercynian composite fold belt of Taimyr is proved for the first time (Samygin, 2012). On the east of the Central Taimyr zone, comprised of the Neoproterozoic rock complexes of diverse geodynamic affinity, there are widespread the allochthonous fragments of the Faddey continental massif with sedimentary cover and a volcano-plutonic belt that were formed in the first half of the Late Riphean. Syn- and postsedimentary tectonic sheets derived from the massif are embedded in or thrust over the deposits of marginal basin, which accumulated in the relatively deep settings during the terminal Late Riphean-early Vendian.

At the time of maximum deepening of the marginal basin, the concurrent isostatic upwarping of the Faddey massif and tilting of its constituent blocks triggered formation of tectonic nappes. Thrust sheets detached from the sedimentary cover of the massif moved toward and slumped into the basin. Growing volumes of allochthonous rock units and products of their destruction accumulated in the basin which became shallower. The ultimate closure of the basin took place, when large fragments of the Faddey massif with remnants of its cover tectonically overrode the relict structures of the basin approximately 
in the Middle Vendian. The Late Baikalian phase of folding affected entirely the Central Taimyr zone and turned it by the Late Vendian into orogen accreted to the Siberian craton as part of the renewed margin, where slope sedimentary facies were deposited in the later epochs.

Two lateral series of the principal Neoproterozoic structures differing in age existed on Taimyr. In the first half of the Neoproterozoic (since $850 \mathrm{Ma}$ at least), it was the ensemble of oceanic plate and continental massif with the suprasubduction volcanoplutonic belt and accretionary wedge in front of the latter. This ensemble was destroyed by tectonic processes that resulted $750 \mathrm{Ma}$ ago in the emergence of the island arc above the accretionary wedge and outer edge of the Faddey massif. Behind thisarc, marginal basin floored by oceanic crust opened at about $730 \mathrm{Ma}$ ago. The new series of paleostructures, which existed in the second half of the Neoproterozoic until $600 \mathrm{Ma}$, included the island arc - carbonate reef belt - back-arc basin - mainly of the continental massif. During the Baikalian and Hercynian orogenies, rock complexes of this structural ensemble were deformed, tectonically imbricated, and fragmented to variable extent, but their initial arrangement relative to each other remained unchanged in general. Fragments of the Faddey continental massif represent an exception.

The Faddey continental massif had a Siberian origin, but its disposition relative to the Siberian paleocontinent before the Neoproterozoic is unknown. In the Neoproterozoic until the Middle Vendian, the massif represented part of the Siberian active margin, the evolution of which included the following succession of geological events: (1) emergence in the massif of a small volcano-plutonic belt, (2) displacement of the magmatic front without a polarity change toward the adjacent oceanic plate and concurrent development of the island-arc system that included the volcanic arc and back-arc basin, (3) the Baikalian orogeny and resultant formation of the new Siberian margin that remained passive during the subsequent epochs.

\section{References}

Bogdanov, N.A., Khain, V.Ye., Rosen, O.M., and Shipilov, E.V., 1998, Explanatory note for the Tectonic Map of the Kara and Laptev Seas and Northern Siberia (scale 1:25000000): Moscow, Institute of Lithosphere of Marginal Seas, pp. 1-116.

Inger, S., Scott, R.A., and Golionko, B.G., 1999, Tectonic evolution of the Taimyr Peninsula, northern Russia: implications for Arctic continental assembly: Journal of the Geological Society, London, v. 156, pp. 10691072.

Kheraskova, T.N., Bush, V.A., Didenko, A.N., and Samygin, S.G., 2010, Breakup of Rodinia and Early Stages of Evolution of the Paleoasian Ocean: Geotectonics, v. 44, pp. 3-24.

Pease, V., Gee, D.G., Vernikovsky, V., Vernikovskaya, A., and Kireev, S., 2001, Geochronological evidence for late-Grenvillian magmatic and metamorphic events in central Taimyr, northern Siberia: Terra Nova, v. 13 , no. 4 , pp. $270-280$.

Pease, V., and Persson, S., 2006, Neoproterozoic island arc magmatism of northern Taimyr: Proceedings of the Fourth International Conference on Arctic Margins, Anchorage, pp. 31-49.

Proskurnin, V.F., Vernikovsky, V.A., Metelkin, D.V., Petrushkov, B.S. et al., 2014, The rhyolite-granite association in the Central Taimyr zone: evidence of accretionary-collisional events in the Neoproterozoic: Geology and Geophysics, no. 1, pp. 23-40 (in Russian).

Samygin, S.G., 2012, Vendian nappes and tectonic evolution of Taimyr in Late Precambrian: Bulletin of Moscow society of naturalists, geol. ser., part 4, pp. 3-19 (in Russian).

Uflyand, A.K., Natapov, L.M., Lopatin, V.M., and Chernov, D.V., 1991, On the tectonic nature of Taimyr: Geotectonics, no. 6, pp. 76-93.

Vernikovsky, V.A., 1996, Geodynamic evolution of Taimyr fold area: Novosibirsk, Siberian Branch of RAS Publishers, pp. 1-203 (in Russian).

Vernikovsky, V.A., and Vernikovskaya, A.E., 2001, Central Taimyr accretionary belt (Arctic Asia): Meso-Neoproterozoic tectonic evolution and Rodinia breakup: Precambrian Research, v. 110, pp. 127-141.

Vernikovsky, V.A., Vernikovskaya, A.E., Pease, V.L, and Gee, D.G., 2004, Neoproterozoic Orogeny along the margins of Siberia: Geological Society, London, Memoirs, v. 30, pp. 233-247.

Zonenshain, L.P., Kuzmin, M.I., and Natapov, L.M., 1990, Geology of the USSR: a Plate Tectonic Synthesis: American Geophysical Union, Geodynamic Series, v. 21, pp. 1-242.

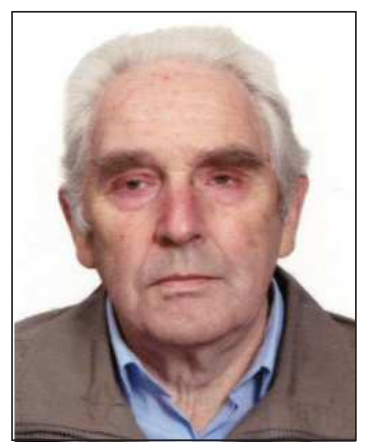

Sergey Samygin, is one of the primary scientists in the Geological Institute of the Russian Academy of Sciences (Russia, Moscow). He got his PhD in Tectonics in 1975. His research interests are geodynamics and tectonics of the Neoproterozoic and Paleozoic rock complexes in the Urals, Siberia, Kazakhstan, and Central Asia. 